\title{
Characteristics and Levels of Mothers' Knowledge about Management of Postpartum Blues Mental Disorder
}

\author{
Indarwati $^{1 *}$, Maryatun ${ }^{2}$ \\ ${ }^{1}$ Universitas Aisyiyah Surakarta \\ ${ }^{2}$ Universitas Aisyiyah Surakarta \\ *E-mail: indarstikes@gmail.com \\ https://doi.org/10.30787/gaster.v19i1.664
}

\section{ARTICLE INFO}

Keywords: Characteristics,

Knowledge, Postpartum

Blues Treatment
ABSTRACT

Background: Postpartum blues is a kind of mental disorder that often experienced by postpartum mothers and it is considered to be fine and believed to resolve itself after a few months. Because it does not bring a problematic case, it will be at risk of becoming depression which has more fatal consequences. The disorder can be resolved immediately if the family members understand the signs of symptom and the treatments that must be conducted. Goal: The study is aimed to know the characteristics and level knowledge of mothers about the treatment of postpartum blues disorder. Method: This study is conducted by cross sectional design and the subject is the mothers who have given birth yet or not yet or the family members. The technique of collecting data uses the android application that completed with questionnaire which designed specifically. The respondents are allowed to fill its online questionnaire with the gadget. Result: The result shows that most of respondents who are in 20 until 35 years old with the highly educated category, and most of them or $96.5 \%$ are as the housewife. Most of those mothers do not understand about the treatment of postpartum blues disorder. The mothers in highly educated category are mostly office employee. Recommendation: the KIE activity about the postpartum blues mental disorder should be held through the Integrated Healthcare Center (Posyandu) or Empowerment of Family Welfare (PKK) activities which collaborated with the Health Care Center in Jetis area. Thus, the further study must be conducted to investigate the difference on both of employee and housewife mothers about the treatment of postpartum blues. 


\section{INTRODUCTION}

The goal of the health building as mentioned in Milennium Development Goals (MDGs) in 2015 is decreasing the infant mortality rate and the maternal mortality rate. The WHO report about the national health status in Sustainable Development Goals mentions that there are 830 deaths if women ub each day because of pregnant complication or childbirth (WHO,2018). The maternal mortality rate reaches 228/100.000 live birth and in 2012, it increases about 359 on each 100.000 live birth (Badan Pusat Statistik, 2012).

The maternal mortality often happens on pregnancy period, when childbirth, and after childbirth, although it can also happen out date of its periods. After childbirth period is a period which has higher potency to get the mood disorder. There is three common type of affective disease after childbirth namely baby blues, after childbirth depression and puerperal pyschosis which are different in prevalency, clinical presentation, and management. About $35 \%$ of 239 respondents in Sarininsih Hospital Bandung get the serious postpartum blues (Fitriana LA and Nurbaiti S (2016). Depression after childbirth can effect to mother's psychological development, influencing the connection among husband, wife, and their children. Therefore, the depression after childbirth is a crucial condition that should be diagnosed, treated, and prevented soon. (Stewart, 2011)

Postpartum period is a crisis situation for mother, her couple, and her family. In this period, everything happens such as the physical and psychological changes or family structure involving adaptation process. Physical adaptation is started since baby born until the comeback of mother's condition before pregnancy, exactly less than 6 until 8 weeks (Fatmawati, 2015). The process of psychological adaptation on a mother has been started since pregnancy. Pregnancy and childbirth is a normal moment which happens in a life, but most of mothers feel stressed significantly. Sometimes, they feel so sad related to their baby. This condition is called as a postpartum blues atau baby blues (Marmi, 2012).

Postpartum blues is often considered as unimportant thing for most of women after childbirth. As consequence, it will be changed to postpartum depression and it does not get good treatment. The stress problem for mother after childbirth can be prevented by communication and education correctly 
during pregnancy. This case is also described by Prihandini (2016) which mentions that postpartum blues can be prevented by education for mothers before getting pregnancy at earlier.

The treatment for mothers who get the mental disorder after childbirth is influenced by their environment such as the role of family. This case is described in Ningrum SP (2017) which mentioned that the social support is quite needed for mothers after childbirth. It is not only from their husband but it also from another family members and people around their environment. It is reasonable because other people around them can have a role as stressor.

The role of actively cadres in giving motivation for mother after childbirth is also quite needed. The cadres are the spearhead of the government who closest with family and they can deliver knowledge and information directly for people as mentioned by Hidayati RW and Mahmudah (2020).

For being active and able to motivate the patients for getting the recovery soon, it needs the enough knowledge about mental disorder for postpartum mother so it can contribute suggestions for patients or family in daily recovery. It is also explained by Prihandini
(2016) in his study about postpartum blues that its mental disorder can be prevented by communicating for mother earlier before pregnancy or when getting postpartum.

From the result from their study, Sari et al (2015) recommend it needs to enrich the understand for society about Post partum blues for mothers because the feeling disorder that will be appeared is very felt after they give childbirth and including on puerperium period. Next, communicating about the knowledge of mental disorder for pregnant women is quiet needed so they can be more ready in facing everything.

The pre-research conducted in Sukoharjo exactly at Jetis through Posyandu activitiy for babies showed that the researchers conducted interview using a telephone for midwidfe and health cadres about the existence of postpartum depression case or postpartum blues. The data shows that there are several mothers who have got depression after childbirth. In the other hand, they do not understand how they treat it. As the consequence, the patients who get the mental disorder are treated in the hospital. Even, there are the husbands who do not know what supposed to do for treating his wife who crying so it makes an emotional feeling and bring bad condition for these 
postpartum mother. The result of interview with one of cadres can be seen as following:

Informant 1;

“...di RW saya bu ada ibu nifas yang mengalami stress, bahkan bayinya saja juga gak dimimiki ASI, kadang menangis sendiri terus ndak maumakan, pinginnya marah terus...suaminya nganti jengkel akhirnya jadi ikut marah pun judeg mungkin ngrasake nyonyahe nikuh seng nangis terus bu"

One of the exploration result to the husband which his wife has faced postpartum blues said that he felt so confused to do what supposed to be when he saw his wife often crying without reasons and never want to give breastfeeding for her baby. The result of interview with the key informant can be seen as following:

"Wingi nyonyah kulo bar lairan koyok tiyang stress bu,..enenge mug nangis wae, malah mboten purun nyusoni..kulo malah melu bingun..judeg kudu piye

From the result of interview above, it can be analyzed that the husband as the family member has not understood about the disorder which faced by the postpartum mother. Therefore, the researchers are interested to analyze deeply about the characteristics and knowledge of mother about the treatment of postpartum blues mental disorder in Jetis Sukoharjo.

Based on the background of problem above, the researchers formulate a problem statement as following: "How is the knowledge level of mother and or family members about the postpartum blues mental disorder after childbirth in Jetis Sukoharjo"?

This study is purposed to identify the knowledge level of mothers and or family members about the postpartum blues mental disorder after childbirth period based on its characteristics.

\section{METHOD AND MATERIAL}

This study is a descriptive survey research with the data collection approach in cross sectional on mothers and or family members who fulfill the criterion of this research. The study is conducted in Jetis Sukoharjo. The population is mothers or family members. The sample is totally 85 respondents. In research procedure, this study is started by requesting permission which approved at workplace of Jetis Sukoharjo. Each subject who fulfilling inclusion criterion is required to assign the letter of approval as participant in this study by fulfilling the online form using android.

Next, the data collection is done by the respondents fulfill google form that designed 
by researchers and it has been tested on its validity and reliability. Totally, 85 respondents fulfill its questionnaire. The communication in this study use the features on Android mobile phone which applied during data collection, so discussion is happened among researchers and respondents if there is any obstacle in fulling its questionnaire.

The analyzing procedure is started by collecting, editing then analyzing and reporting. On editing step, the researchers check data up before they analyze data such as respondent's identity and material substance that has been fulfilled. After the data is ready to process, it is put in excel program then transferred to SPSS program. Then, data analysis is conducted univariately and described into the report using the frequency distribution table.

The main variable of this study is mother characteristics (age, educational level, and job status) and knowledge about the treatment of postpartum blues mental disorder. The age variable is the count of years of life calculated based on the year of birth of the respondents to the current year of data collection. In measuring scale, variable of educational level is graduates of the respondent's school until they get a certificate which categorized into four categories ( 0 : primary school, 1: Junior High School, 2: Senior High School, 3: University). Then, the next variable is working status that means respondent status (working or not) when fulfilling the questionnaire data. They may be an office employee, government official, teacher, farmer, even factory employee. Working is meant as the act in getting money. In this current study, they are categorized as 1: entrepreneur, 2: government official, 3: office employee, 4: teacher, 5: housewife, and 6: merchant.

The variable of knowledge level about the treatment of postpartum blues mental disorder is the respondent answer of the question about it which consists of the questions around the case of rest time estimation, the connection of harmful communication by the patient, the patient's accompaniment in giving care for baby with two categories namely know and not know.

\section{Data Analysis and Statistics Test}

Data analysis in this study is conducted by univariate analysis. It is purposed to identify the characteristics of the research subject and to describe the knowledge level about the treatment of postpartum blues mental disorder with using the view of distribution frequency table. 


\section{RESULT AND DISCUSSION}

The result of the study shows the characteristics of mothers in scope of knowledge level about the management of postpartum blues mental disorder which can be seen on the table 1 as following:

Table 1. Mothers' Characteristics Based on Age, Educational Level, and Job Status

\begin{tabular}{ll} 
Characteristics & Frequency (\%) \\
\hline Age & \\
1. Under 20 year old & $3(3.5)$ \\
2. 20 -35 years old & $44(51.8)$ \\
3. Over 35 years old & $38(44.7)$ \\
Educational Level & \\
1. Primary School & $1(1.2)$ \\
2. Junior High School & $4(4.7)$ \\
3. Senior High School & $13(15.3)$ \\
4. University & $67(78.8)$ \\
Job Status & \\
1. Enterpreneur & $13(15.3)$ \\
2. Government Official & $10(11.7)$ \\
3. Office Employee & $14(16.5)$ \\
4. Teacher & $11(12.9)$ \\
5. Housewife & $35(41.2)$ \\
6. Mercant & $2(2.4)$ \\
\hline Total & $85(100)$ \\
\hline
\end{tabular}

Table 1 shows the insight of the mothers' characteristics such in age category, the most of them aged is in 20 - 35 years old $(51.8 \%)$; in the educational level category, most of mothers who get highly educated are 78.8 $\%$ and the lowest educated mothers are in primary school $(1.2 \%)$; then in job status category, most of respondents who work as housewife are totally 35 mothers (42\%).

The discussion of this study is conducted on main variable namely characteristics and knowledge of mothers about the pospartum and postpartum blues depression mental disorder.

Based on the table 1 which attached about mothers characteristics shows that most of them are in $20-35$ years old. These age is very healthy for a mother who wants to get pregnant. The finding is very related against the previous study from Prihandini, et al (2016) which described that pregnancy mothers in aged under than 20 years old and over 35 years old were very risk to get abortus. It means that if a woman get pregnancy in age among 20 - 35 years old, she can be more safely and ideal. This assumption is in line with a theory which describing that the 20 until 35 years old have been ready physically to get the pregnancy because its reproductive organs have grown strongly and maturely to a conception process. Nevertheless, this study indicates that there are still age under 20 years old totally 3 respondents and over 35 years old totally $44.7 \%$. 
The age characteristic is considered as the research variable because a previous study describes that most of respondents $(88 \%)$ who aged in under 20 years old have experienced postpartum blues (Fatmawati DA, 2015).

Then, the result related to mothers characteristics can be seen based on the educational level shows that most of mothers from Jetis as respondent have highly educated.

Based on the result of this study, it can be assumed that people of Jetis are a grup of society who get qualified education so it is possible and easier to receive knowledge that can influence in attitude and act.

Related to job status, this study shows that most of mothers and or the family members as respondent are housewife, it means that they just functioned surely as housewife who provide care for children and the household, not for getting money.

This characteristic is analyzed because of the description by Rami R (2020) that social interaction which done by someone will enrich the knowledge. If it is analyzed in this study, it will show that most of mothers of Jetis Sukoharjo are housewife who have a little bit of opportunities to interact others.

Next, the description of the result related to characteristics and knowledge level of respondents about the postpartum blues treatment can be seen on table 2 as following:

Table 2. The Knowledge Level of Respondents about the Treatment of the Postpartum Blues Mental Disorder Case based on the Characteristics (Educational Level and Mothers' Job Status)

\begin{tabular}{lcc}
\hline Characteristics & \multicolumn{2}{c}{ Knowledge Level } \\
\cline { 2 - 3 } & Know & Not Know \\
\hline Educational Level & & 1 \\
1. Primary School & 0 & 4 \\
2. Junior High School & 0 & 13 \\
3. Senior High School & 0 & 64 \\
4. University & 3 & $\mathbf{8 2}$ \\
Total & $\mathbf{3}$ & \\
Jobs Status & & 1 \\
1. Enterpreneur & 12 & 9 \\
2. Government Official & 1 & 14 \\
3. Office Employee & 0 & 10 \\
4. Teacher & 1 & 35 \\
5. Housewife & 0 & $\mathbf{7 1}$ \\
\hline Total & $\mathbf{1 4}$ & \\
\hline
\end{tabular}

The description on table 2 above shows that most of respondents on educational level is categorized into highly educational level, but most of them do not know the treatment of postpartum blues mental disorder patients. Even, they who know it in highly educational 
level are tottaly 3 respondents. This result gives the view of the knowledge of someone is not influenced by the higher educational level. It is in line with the statement of Simanungkalit (2018) and Sari, et al (2015) that the higher level in education is not able to be guarantee of the knowledge level of someone. The study by Sari, et al (2015) described clearly that the knowldge of postpartum mothers in Banjarmasin was not different towards mothers who got education in Junior High School, Senior High School, and University.

It is contrasted with the result of study by Afwatunati, et al (2016) and Rahayu, et al (2014) which described that the respondents who got higher education actually have the higher knowledge than they who got it in primary school. Thus, both of researchers describe that the knowledge is related significantly against the education. The difference of this current research with previous studies does not need to be a problem. It is reasonable because the data collection of the current research is quiet different against previous studies which using direct observation so the respondents can discuss if they do not understand various questions. While, data collection of the current reseach applies online system which makes the researcher cannot explain clearly about the content of questionnaire for respondents.

Related to the job status in this study, it shows that most of mothers and health cadres are housewife. It means that they just have the role as housewife who providing the care for children and household, it is not purposed to get the money. This characteristic is studied by the reseacher based on the asumption by Rami R (2020) which explained that social interaction which done by someone would enrich the knowledge for mothers. When it is related to the result of this research, most of mothers in Jetis Sukoharjo are housewife, as the consequence, the opportunity in interacting with others is very low, then they probably get less information about the postpartum mental disorder.

The source of knowledge can be obtained from various sources and experiences such as from friends, from family members, from mass or printing media, and knowledge from the health practitioners. The result of this research shows that most of respondents are housewife, so there is a big opportunity that the interaction is just connected to others such as their neighboors and family members. It effects to the limitness of knowledge for them. It limitness can be a risk to their daily health acts as explained by Sudar, RF (2020) study 
about the act of waste management which indicated that the good knowledge level of mothers was tend to be better in doing its act.

The other result on job status and educational level shows that there are none of mothers who working as office emloyee and housewife know the postpartum treatment, otherwise, there are 12 mothers who working as enterpreneur know it.

This result needs to be studied deeply to investigate why the housewife have more leisure time rather not knowing about the postpartum treatment and whether they never try to find it or not. While, the mothers who work as office employee are easier to access the knowledge of it, but in fact, it is actually contradicted. Related to the fact, this study shows that they are who work as office employee $(0 \%)$ do not the way to give the treatment for pospartum blues.

The mothers as housewife who do not know about the way in giving postpartum blues treatment are predictable caused by they are uninterested to these case so they do not try harder to find it. Then, the mothers who work as enterpreneur are almostly knowing it because they can obtain much information through mass media in electronically or non electronically.

\section{CONCLUSION AND RECOMMENDA-} TION

Based on the result that have been explained, it can be assumed that the characteristic of respondents showing such as the most of them are in productive age, having highly educated, and working as housewife.

Viewing from the discussion about knowledge level, it shows that most of respondents still do not know how the way to give the treatment of postpartum blues correctly. While, the result and discussion related to the characteristics of respondents and the level of knowledge about the management of the postpartum blues mental disorder patients can be concluded that the highly educated level and housewife status cannot be a guarantee of someone knowing about health knowledge. Furthermore, this study produces a hypothesis that "there is a different treatment of the postpartum blues patients who have the highly educated level and working as housewife".

\section{REFERENCE}

\section{Journals}

Afwatunati, Sunarko, \& Setyaningsih, W. (2016) Pengaruh Pengetahuan Terhadap Sikap Ibu Rumah Tangga 
Dalam Upaya Mengatasi Pencemaran

Lingkungan Akibat Sampah dui TPA

Jatibarang, Jurnal Edu Geography. 4.

Fatmawati, D. (2015). Faktor Risiko Yang

Berpengaruh Terhadap Kejadian

Postpartum Blues, Jurnal Edu Health, Vol. 5 No. 2 ,

Fitriana, L.A., \& Nurbaiti S. (2016).

Gambaran Kejadian Postpartum

Blues Pada Ibu Nifas Berdasarkan

Karakteristik Di Rumah Sakit Umum

Tingkat Iv Sariningsih Kota Bandung,

Jurnal Pendidikan Keperawatan

Indonesia Vol.2 No. 1

Hidayati RW \& Mahmudah N. (2020).

Peran kader Ranting 'Aisyiyah Cabang

Kota Yogyakarta dalam pemberdayaan masyarakat di bidang kesehatan, Jurnal Kebidanan . Vol 9, No 1

Ningrum, S. P. (2017). Faktor-Faktor

Psikologis yang Mempengaruhi

Postpartum Blues, Jurnal Ilmiah

Psikologi, vol 2 no 4

Prihandini, S.R., Pujiastuti, W., \& Hastuti, T. P. (2016). Usia Reproduksi Tidak Sehat Dan Jarak Kehamilan Yang Terlalu Dekat Meningkatkan Kejadian
Abortus Di Rumah Sakit Tentara Dokter Soedjono Magelang, Journal Kebidanan, vo 5, no 9

Ramli, R. (2020) Hubungan Pengetahuan dan Status Pekerjaan Ibu dengan Pemberian ASI Eksklusif di Kelurahan Sidotopo.: The Indonesian, Journal of Health Promotion and Health Education, Vol. 8 No. 1, 36-46

Sari A., Basit M, R \& Adawiyah, R. (2015). Gambaran Pengetahuan Ibu Nifas Tentang Post Partum Blues Di Rsud.Dr. H. Moch. Ansari Saleh Banjarmasin, Dinamika Kesehatan, Vol. 6 No 2

Simanungkalit, H. M. (2018) Status Pekerjaan Dan Pengetahuan Ibu Menyusui Terhadap Pemberian ASI Eksklusif, Jurnal Info Kesehatan, Vol 16, No.2, pp. $236-244$

Stewart, D. E. (2011). Depression during pregnancy. N Engl J Med. 365:1605-11.

Sudar, R. F. (2014). Hubungan Antara Karakteristikindividu Dan pengetahuan masyarakat dengan Tindakan Pengolahan sampah Rumah tangga Di Desa borgojaga V Kecamatan Tombariri Kabupaten minahasa, Jurnal IKHA, no 3 


\section{Information from Internet}

Rahayu, C.., Widiati, S.., \& Widyanti, N. (2014). Hubungan antara Pengetahuan, Sikap, dan Perilaku terhadap Pemeliharaan Kebersihan Gigi dan Mulut dengan Status Kesehatan Periodontal Pra Lansia di Posbindu Kecamatan Indihiang Kota Tasikmalaya. Maj Ked Gi. 21(1): p; 27-32https://jurnal.ugm.ac.id/public/ journals/62/pageHeaderTitleImage en_US.jpg

Profil Kesehatan Provinsi Jawa Tengah. (2015). Data Angka Kematian Ibu dan Bayi. Semarang, Jawa Tengah: Penulis. www.dinkesjatengprov.go.id

BPS. BKKBN., Kementrian Kesehatan Indonesia. (2018). Hasil Survei Kesehatan Indonesia, Jakarta. https:// e-koren.bkkbn.go.id/wp-content/ uploads/2018/10/Laporan-SDKI-2017WUS.pdf
WHO. (2018). Monitoring health for the SDGs, sustainable development goals World health statistics 2018: monitoring health for the SDGs, sustainable development goals https://apps.who.int/iris/bitstream/ handle/10665/272596/9789241565585 eng.pdf? sequence $=1 \&$ isAllowed $=\mathrm{y}$

Gaynes, B. N., Gavin, N., Meltzer-Brody, S., Lohr, K. N., Swinson, T., \& Gartlehner, G. (2005). Perinatal depression: prevalence, screening, accuracy and screening outcomes. Evid Rep Technol Assess (Summ). 119;1-8., https://www. ncbi.nlm.nih.gov/books/NBK11838/

\section{Book}

Marmi. (2012). Asuhan Kebidanan pada Masa Nifas "Puerperium Care". Yogyakarta: Pustaka Pelajar

\section{Book without Author}

Badan Pusat Statistik. (2012). Survey Demografi dan Kesehatan Indonesia: Jakarta: Kemenkes RI 